$\xi=1$ 圈

\title{
Determination of liquefaction potential for two selected sites in Kerbala city- middle of Iraq
}

\author{
Hamed H. Abdullah ${ }^{1 *}$, Mohammed Y. Fattah ${ }^{2}$, Abdulkareem H. Abed ${ }^{3}$ \\ ${ }^{1}$ Assistant Professor, Bagdad University, College of Science, Department of Geology, Iraq \\ ${ }^{2}$ Professor, Building and Construction Engineering Dept., University of Technology, Iraq \\ ${ }^{3}$ Lecturer Babylon University, College of Science, Department of Applied Geology, Iraq \\ *Corresponding author E-mail:
}

\begin{abstract}
Geotechnical characterization of the sites has been investigated with the collection of borehole data from different sources. Using the data, grain size distribution curves have been developed to understand the particle size distribution of the alluvium present. These curves were further used for preliminary assessment of liquefiable areas. From geotechnical characterization, it has been observed that the soil profile in the two sites is dominated by sand and silty sand.

Seed and Idriss (1971) approachhas been usedevaluatethe liquefaction potentialbydeterminationof the relation between the maximum ground acceleration (a max/g) valuesdue to an earthquake and the relative density of a sand deposit in the field. The results reveal that the study area will be subjected to occurrence of liquefaction under an earthquake of maximum ground acceleration of $0.1 \mathrm{~g}$ when the soil is loose with a relative density between (25-40) \% in Kerbala city.

Design chartswere obtained for determination of liquefaction potentialin any layer with knowingthe field relative densityand the value of the maximum ground surface acceleration.
\end{abstract}

Keywords: Liquefaction Potential; Relative Density; Kerbala City; Maximum Ground Surface Acceleration.

\section{Introduction}

There is a general problem in the weak areas of an earthquake zones, on account of the existing of loose saturated soil deposits. This general trouble is called liquefaction. The loss of strength or stiffness of the ground results in the settlement of buildings, failure of earth dams, landslides and other hazards. The process by which loss of strength occurs in saturated sandy and silty sand soil is called soil liquefaction. The phenomenon of soil liquefaction is primarily associated with medium to fine-grained saturated cohesionless soils.

Someof previous studies that are related to study of liquefaction potential are summarized below:

Piya, [1] studied the susceptibility of the material to liquefaction and assessment of liquefaction hazard in Kathmandu valley. Hence an attempt has been made to prepare a liquefaction susceptibility map for the valley. Qualitative and quantitative methods were used for most of the area.

Karim et al. [2] evaluated some geotechnical properties and liquefaction potential from seismic parameters for 14 sites located within the Mesopotamian plain and surroundings. LiuefyPro software was utilized for two selected Iraqi sites to investigate the liquefaction potential. The resultsshowed a total settlement for the saturated and dry sand of $32 \mathrm{~mm}$ for the first site while no settlement has been indicated for the second site.

Kahraman, [3] studied liquefaction phenomena in sands and silty sands. Instrumentations were used during shake table tests to measure laminate, soil response and settlement of ground. Piezocone penetration tests (CPTu) were conducted before and after each shake to determine the relative density of the soil model. The results showed that silty sands were found to possess more liquefaction resistance than uniform fine sands. Relative density values increased with each shake. Ground settlement values have increased with fines content of the soil model.

Giannakogiorgos, et al., [4] presented the combined liquefaction case histories data from the 2010 - 2011 Canterbury earthquake sequence (CES) and the Emilia-Romagna region (Northern Italy) 2012 earthquake, on the recently proposed Liquefaction Potential Index (LPI)-Liquefaction Severity Index (LSN) classification chart. The revised LPI-LSN chart classes I, II and IV, are in reasonable agreement with the distribution of cases from Christchurch area and can be used for the initial site characterization.

The present study aims to assess the site-specific liquefaction potential based on the procedure of Seed and Idriss, [5].

\section{The study area}

The study area lies withina zone of minor damage which follows magnitudes $\mathrm{MM}=\mathrm{IV}$ to $\mathrm{V}$ and covers the Mesopotamian zones, one the basis of seismic zoning maps (Alsinawi and Ghalib, [6] and Alsinawi and Al-Qasrani, [7]).The study area lies nearly at $105 \mathrm{~km}$ southwest of Baghdad governorate, which is located at the middle of Iraq in Kerbala governorate. The rise of Kerbala city is about $40 \mathrm{~m}$ above the sea level, coordinate at (Longitude. $43^{\circ} 58^{\prime} \mathrm{E}$ - $44^{\circ} 01^{\prime} \mathrm{E}$ and Lattiude. $32^{\circ} 34^{\prime} \mathrm{N}-32^{\circ} 39^{\prime} \mathrm{N}$ ), as shown in Figure 1. 


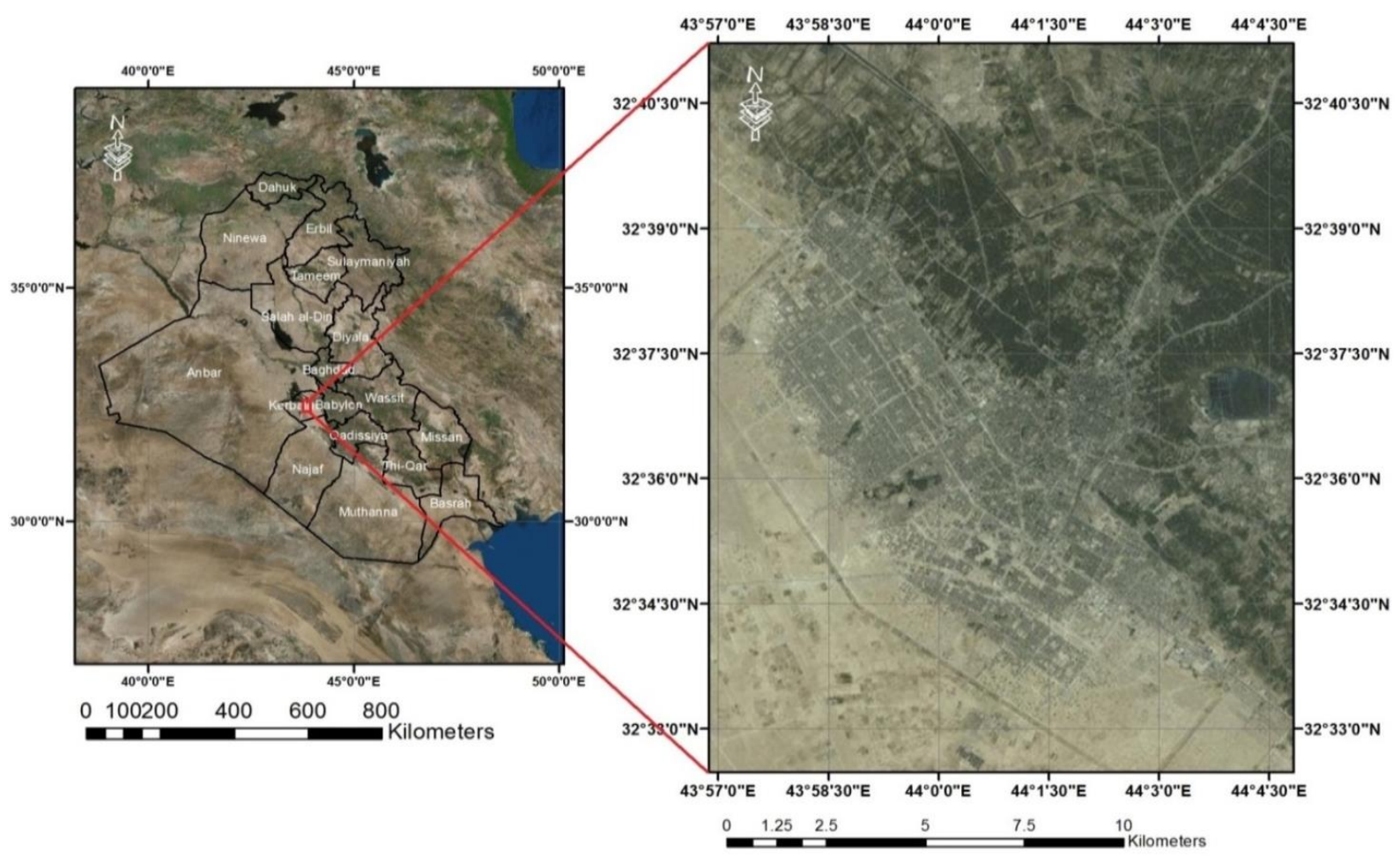

Fig. 1: Location Map of the Project Area.

\section{Geological setting of the study area}

The stratigraphic units exposed in the Kerbala area, are as illustrated in Table 1 while Figure 2 shows geological map for the study area.

\section{Methodology}

All of the available publications about the study area (journals, papers, theses, reports )about soil investigation reports and seismic data were collected from various public and private organizations, maps including, geologic maps and satellite images and studied in order to make a better idea about the study area.

Two projects were selected in Kerbala city. In the first project, the soil investigation was carried out at April/ 2016,while the second project investigation was done in June / 2012. The first borehole is located in Kerbala governorate inside the new Kerbala Laboratory Building (NKL) which is about (10) km from Kerbala city center. The second borehole was selected for the Abasiya Hotel Site (K3).The standard test methods ASTM D-1452 [8] and D-5783 [9] were followed with boring depth reached 10 meters from the natural ground surface inside the new Kerbala Laboratory Building. About 15 soil samples were taken from these drilled boreholes at various depths. The standard penetration test (S.P.T.) was performed in the field. Laboratory tests were conducted in the National Center for Construction Laboratories (NCCL) in Hilla city, and the performed laboratory tests in this stage include the tests listed in Table 2.

After the completion of the previous stages, the required data were calculated by using the procedure of Seed and Idiress, [5] for the ground response analysis.

Table 1: Geological Setting of the Study Area

\begin{tabular}{|c|c|c|c|}
\hline No. & Geological Time & Formation name & Geology description \\
\hline 1 & Upper Miocene & Injana Formation & $\begin{array}{l}\text { Lower Clastic Unit It consists of analternation of different clastic rocks } \\
\text { (claystone, sandstone and siltstone) or admixture of these rocks in differ- } \\
\text { ent ratios. and Upper Claystone Unit It consists of claystone, occasionally } \\
\text { silty, brown to reddish brown, conchoidally fractured, massive, tough, } \\
\text { cliff-forming, changes laterally or vertically to silty claystone (Hassan, } \\
\text { [10]). }\end{array}$ \\
\hline 2 & Pliocene - Pleistocene & Dibdibba Formation & $\begin{array}{l}\text { Sand and gravel, as well quartz, chert, carbonate and clay(Bellen et al., } \\
[11]) \text {. }\end{array}$ \\
\hline \multirow{5}{*}{3} & \multirow{5}{*}{ Paleocene and Holocene } & \multirow{5}{*}{ Quaternary deposits } & 1-Aeolian deposits: \\
\hline & & & 2- Depression fill sediments: \\
\hline & & & 3- Colluvial sediments: \\
\hline & & & 4- Gypcrete deposits \\
\hline & & & $\begin{array}{l}\text { 5-Inland-Sabkha (Al-Khateeb and Hassan, [12] and Barwary and Sliawa, } \\
[13]) \text {. }\end{array}$ \\
\hline
\end{tabular}



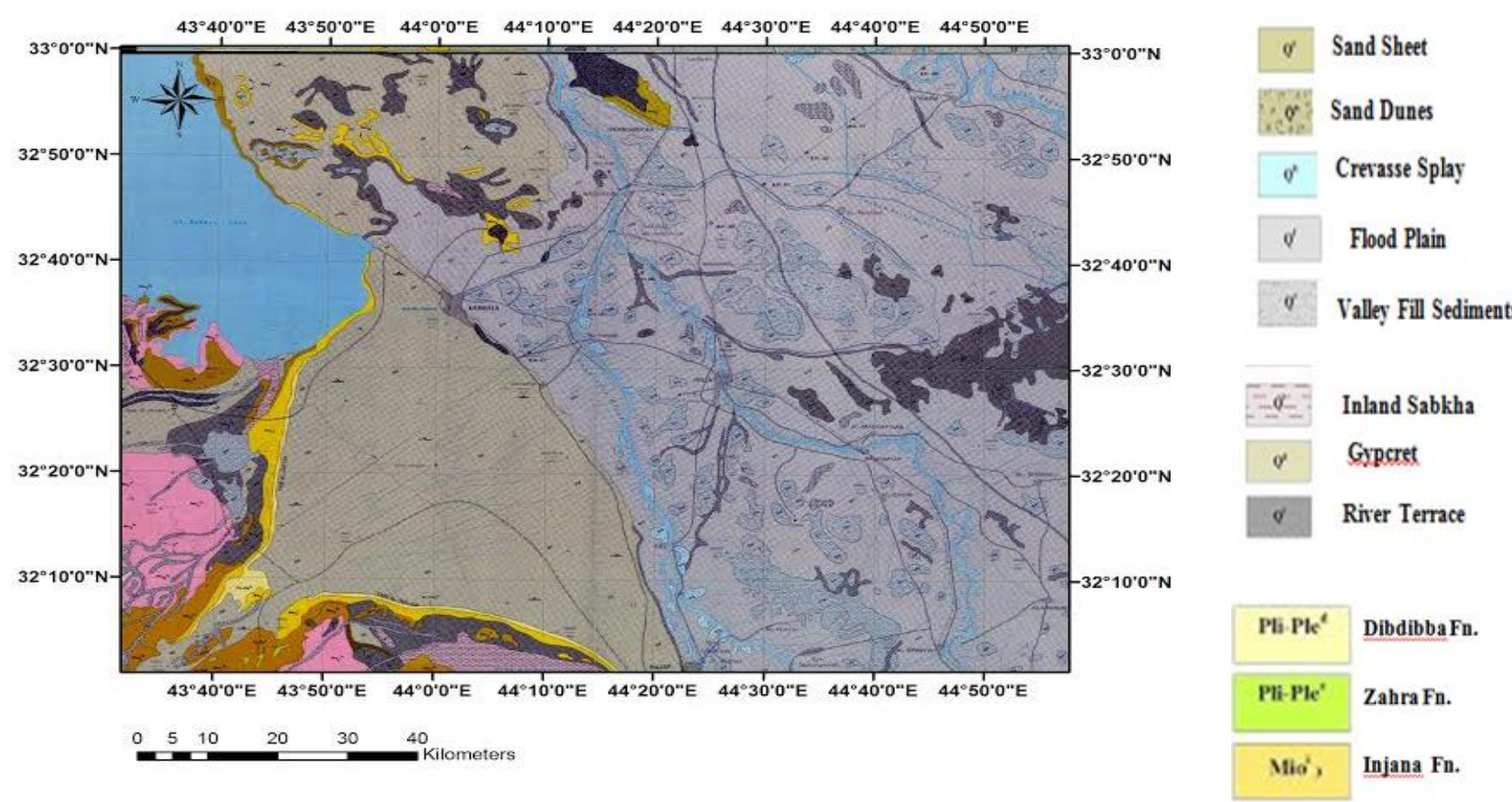

Fig. 2:AGeological Map of the Study Area (Barwaryand Slewa, [13])

Table 2: Laboratory Tests and Specifications for Each Test

\begin{tabular}{lll}
\hline Test Types & Number samples tested & Test Methods \\
\hline Moisture content & 10 & (ASTM- D 2216-12) [14] \\
Atterberg limits & 3 & (ASTM-D4318-12) [15] \\
Specific gravity & 3 & (ASTM - D854-12) [16] \\
Grain size analysis & 12 & (ASTM - D422-12) [17] \\
Classification of soils & 6 & (ASTM D-2487-12) [18] \\
\hline
\end{tabular}

\section{Results of field and laboratory tests}

This section includes results of geotechnical, dynamic and field tests, on soils tested in the laboratory or field, which include: moisture content, grain size analysis, Atterberg limits (liquid limit and plasticity index), soil layer density and water table level detection.
Grain size distribution curves to some depths of soil profile samples are shown in Figures 3 and 4. Results of some important geotechnical and dynamic properties for two sites: K3 and NKL are shown in Tables 3 and 4. Borehole log for (K3) site is shown in Figure 5 in Kerbalacity, while for New Kerbala Laboratory Building in Kerbala city the borehole log is shown in Figure 6.

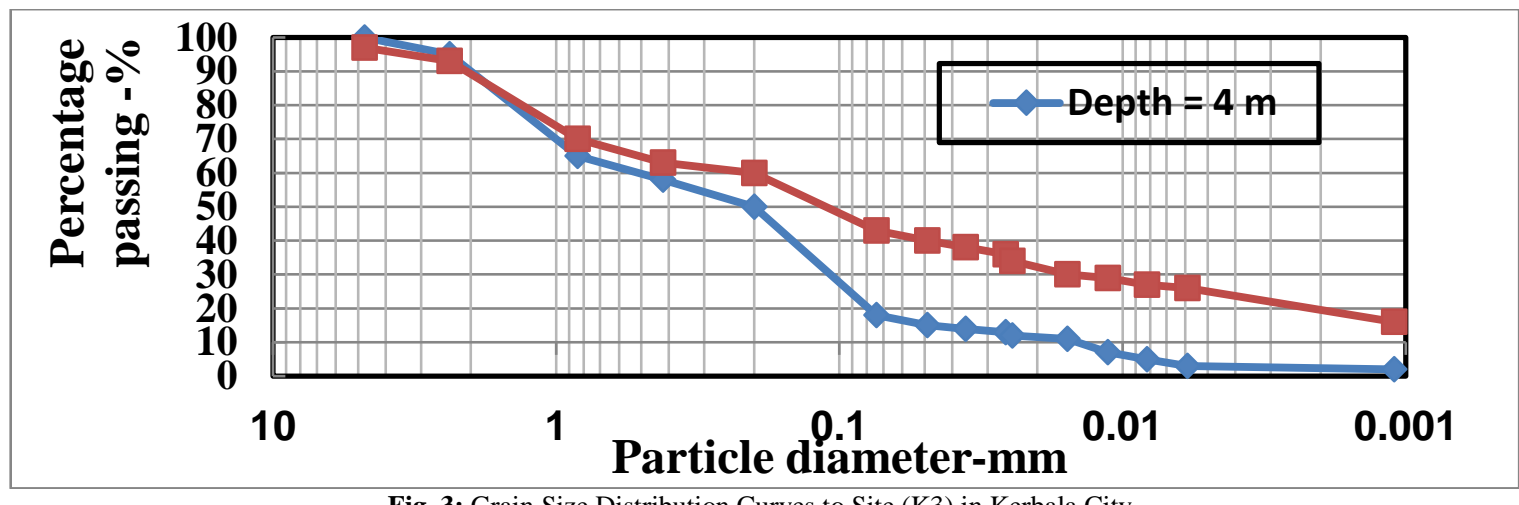

Fig. 3: Grain Size Distribution Curves to Site (K3) in Kerbala City. 


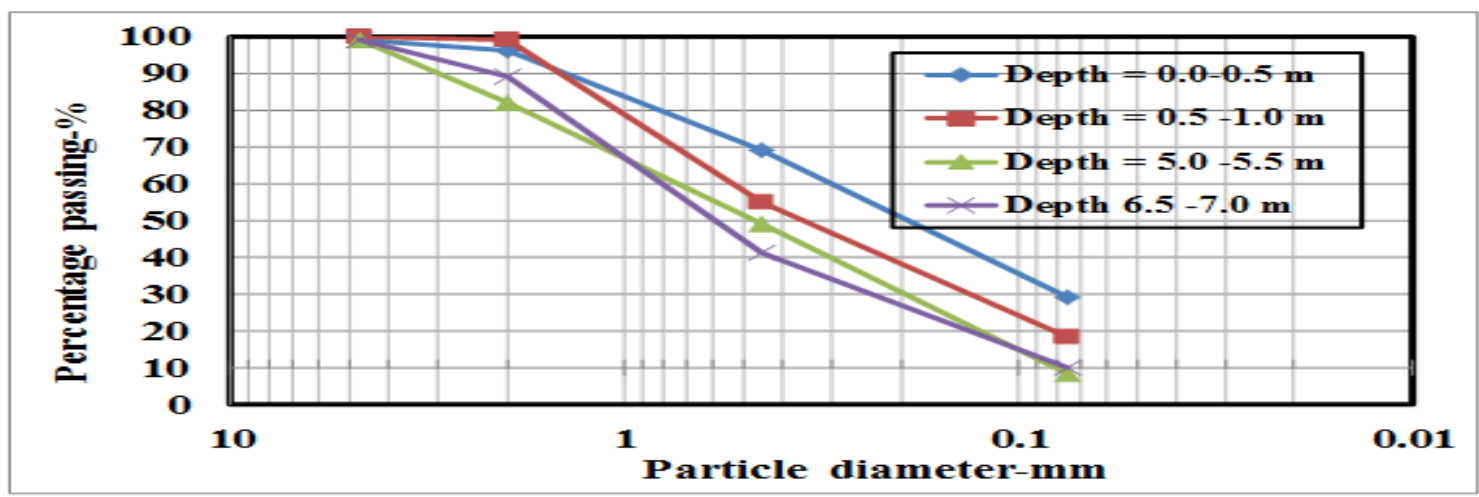

Fig. 4: Grain Size Distribution Curves for Site (N.K.L) in Kerbala City.

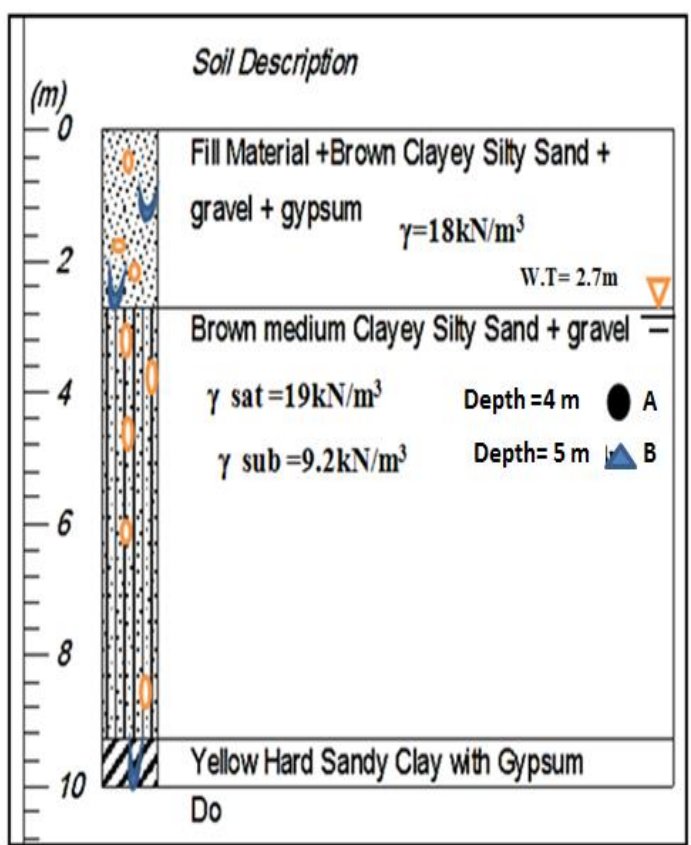

Fig. 5: Soil Profile for Site K3 in Kerbala City and Some Physical Properties.

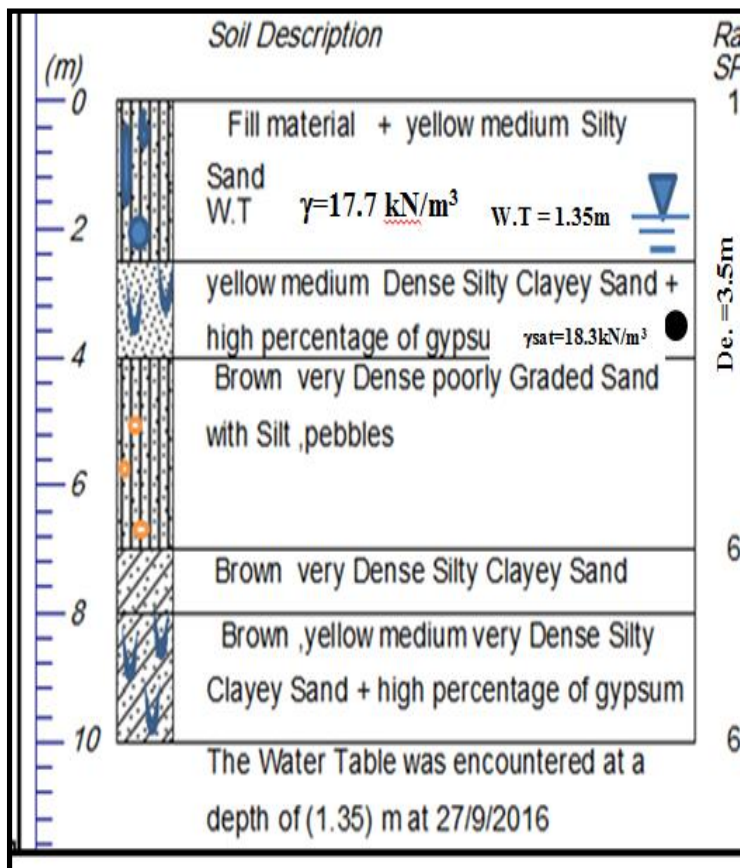

Fig. 6: Soil Profile for Site NKL in Kerbala City and Some Physical Properties.

Table 3: Geotechnical and Dynamic Properties to the(Abasiya Hotel) K3 Site

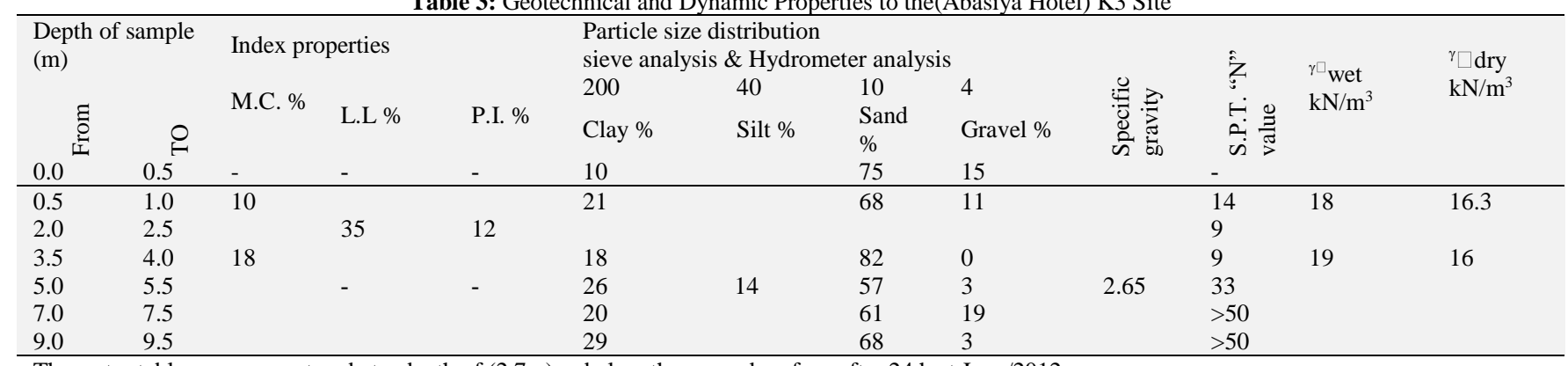

The water table was encountered at a depth of $(2.7 \mathrm{~m}) \mathrm{m}$ below the ground surface after $24 \mathrm{~h}$ at June/2012

Table 4: Geotechnical and Dynamic Properties to the New Kerbala Laboratory Building (N.K.L)

\begin{tabular}{|c|c|c|c|c|c|c|c|c|c|c|c|c|}
\hline \multicolumn{2}{|c|}{$\begin{array}{l}\text { Depth of sample } \\
\text { (m) }\end{array}$} & \multicolumn{3}{|c|}{ Index properties } & \multicolumn{3}{|c|}{$\begin{array}{l}\text { Particle size distribution } \\
\text { sieve analysis \& Hydrometer analysis }\end{array}$} & \multirow[b]{2}{*}{4} & \multirow{3}{*}{ 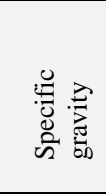 } & \multirow{2}{*}{ 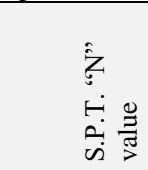 } & \multirow{3}{*}{$\begin{array}{l}{ }_{\mathrm{wet}} \\
\mathrm{kN} / \mathrm{m}^{3}\end{array}$} & \multirow{3}{*}{$\begin{array}{l}{ }^{\gamma} \text { dry } \\
\mathrm{kN} / \mathrm{m}^{3}\end{array}$} \\
\hline 总 & $\stackrel{0}{H}$ & $\begin{array}{l}\text { M.C. } \\
\%\end{array}$ & $\begin{array}{l}\text { L.L } \\
\%\end{array}$ & $\begin{array}{l}\text { P.I. } \\
\%\end{array}$ & $\begin{array}{l}200 \\
\text { Clay \% }\end{array}$ & $\begin{array}{l}40 \\
\text { Silt } \%\end{array}$ & $\begin{array}{l}10 \\
\text { Sand } \%\end{array}$ & & & & & \\
\hline 0.0 & 0.5 & 2 & - & - & 29 & & 70 & 1 & & - & & \\
\hline 0.5 & 1.0 & 4 & - & - & 18 & & 82 & 0 & & 10 & 17.7 & 17.0 \\
\hline 2.0 & 2.5 & 18 & - & - & & & & & & 15 & & \\
\hline 3.5 & 4.0 & 13 & - & - & & & & & & $42 / 150 \mathrm{~mm}$ & & \\
\hline 5.0 & 5.5 & 14 & - & - & 8 & & 82 & 10 & & $42 / 150 \mathrm{~mm}$ & 18.3 & 16.1 \\
\hline 6.5 & 7.0 & 15 & - & - & 11 & & 87 & 2 & & $42 / 150 \mathrm{~mm}$ & & \\
\hline 8.0 & 8.5 & 24 & 27 & 15 & 27 & 17 & 54 & 2 & 2.66 & $>50$ & 18.6 & 15.0 \\
\hline 9.5 & 10.0 & 24 & 28 & 13 & 12 & 18 & 68 & 2 & 2.65 & $42 / 150 \mathrm{~mm}$ & & \\
\hline
\end{tabular}

The water table was encountered at a depth of (1.35) m below the ground surface after $24 \mathrm{~h}$ at 27/9/2016. 
Determination of Liquefaction Potential in the Field

In this section, the method of Seed and Idriss, [5] will be used to investigate the liquefaction potential of the two sites.

Case No. 1: Abasiya Hotel Site.

From the site investigation and the soil profile is illustrated in Figure 5:

W.T.L. $=2.7 \mathrm{~m}, \mathrm{D}_{50}=0.2 \mathrm{~mm}$, depth $=4 \mathrm{~m}$, S.P.T. $=9$ blows $/ 30$ $\mathrm{cm}$, field relative density $\mathrm{R}_{\mathrm{D}}$ at a depth $4 \mathrm{~m}=30 \%$. Based on Figure (7), the significant number of stress cycles $=3.5$ for earthquake magnitude $=4$.

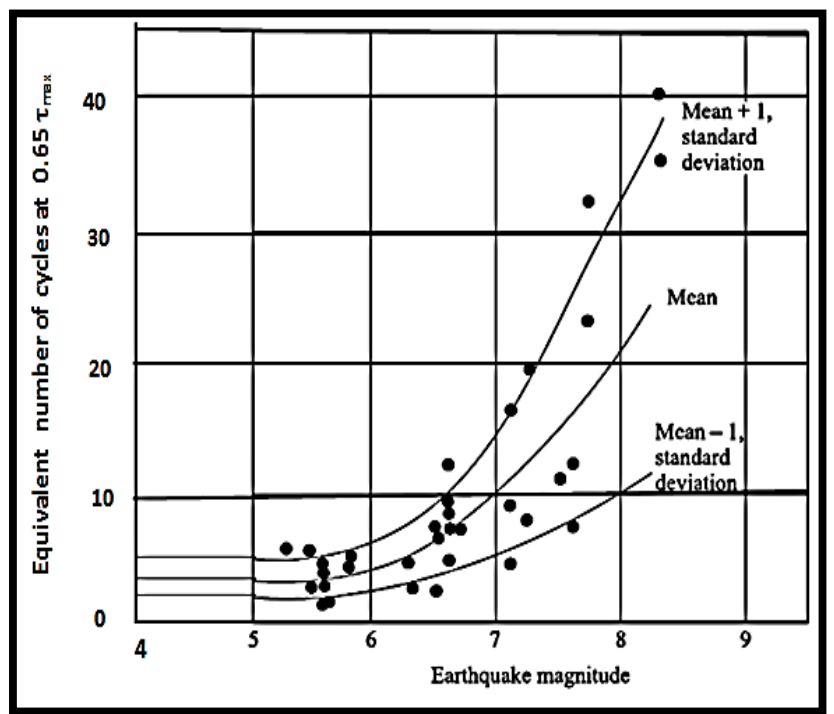

Fig. 7: Equivalent Numbers of Uniform Stress Cycles Based on Strong Component of Ground Motion (Modified from Seed Et Al., [19]).

According to the steps for Seed and Idriss method, one can prepare the data as in the Table 5. It is possible to determine liquefaction potential at point A (shown in Figure 5):

1) Calculation $\left(\tau_{\mathrm{av}}\right)$ from following equation (Seed and Idriss, [5]):

$\tau_{\mathrm{av}}=0.65 \tau_{\max (\operatorname{modif})}=0.65 \mathrm{r}_{\mathrm{d}}\left[\left(\frac{\gamma \mathrm{h}}{\mathrm{g}}\right) \mathrm{a}_{\max }\right]$

where:

$\tau_{\mathrm{av}}=$ The average equivalent uniform shear stress is about 65 percent of the maximum shear stress,

$0.65=$ Weighting factor,

$\tau_{\text {Max }}=$ the maximum shear stress,

$\mathrm{a}_{\max }=$ maximum ground surface acceleration,

$\mathrm{h}=$ depth,

$\gamma=$ the unit weight of soil, and

$\mathrm{g}=$ acceleration due to gravity.

While the stress reduction factor $\left(r_{d}\right)$ determined from Figure 8according to specified depth.

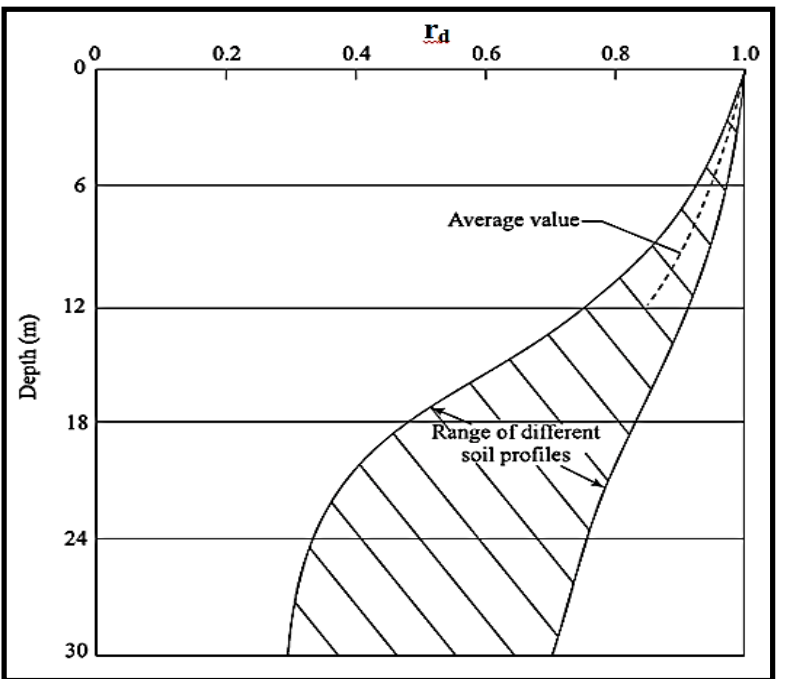

Fig. 8: Reduction Factor to Estimate the Variation of CSR with Depth below the Ground Level or Gently Sloping Ground Surface (after Seed and Idriss, [5]).

2) this calculated from following equation, while $\mathrm{Cr}$ is determined from Figure 9

One can now combine Eq. (2), which gives the correlation of laboratory results of cyclic triaxial test to the field conditions, and Eq. (1) to determine the relationships between $a_{\max }$ and $R_{D}($ Das and Ramana, [20]):

$\left(\frac{\tau_{h}}{\sigma_{v}}\right)_{\text {field }\left[\mathbf{R}_{\mathrm{D}(2)}\right]}=\mathbf{C}_{\mathbf{r}}\left[\frac{\frac{1}{2} \sigma_{\mathrm{d}}}{\sigma_{3}}\right]_{\operatorname{triax}\left[\mathbf{R}_{\mathrm{D}(1)}\right]} \cdot \frac{\mathbf{R}_{\mathrm{D}(2)}}{\mathbf{R}_{\mathrm{D}(1)}}$

where:

$R_{D(2)}$ is the relative density in the field,

$R_{D}(1)$ is the relative density in the laboratory,

$\tau_{\mathrm{h}[\mathrm{RD}(1)]}$ is the cyclic peak shear stress required to cause initial liquefaction inthe laboratory for a given value of $\sigma_{\mathrm{v}}$ and number of cycles, by simple shear test, and

$\tau_{\mathrm{h}[\mathrm{RD}(2)]}$ is the cyclic peak stress required to cause initial liquefaction in the field for the same value of $\sigma_{\mathrm{v}}$ and number of cycles, by simple shear test. The variation of the correction factor $C_{r}$ with relative density can be obtained from Figure (9).

3) The stress ratio $\square \mathrm{d} / 2 \square 3$ was determined from Figure (10)according to D50 value.

Figure (10) is a plot of stress ratio $\left\{\frac{\sigma_{\mathrm{d}}}{2 \sigma_{3}}\right\}$ versus $\mathrm{D}_{50}$ to cause initial liquefaction in 3.5 cycles of stress application. The plot is for an initial relative density of compaction of $50 \%$. It is noted that $\mathrm{D}_{50}$ in Figure (10) is the mean grain size, i.e., the size through which $50 \%$ of the soil will pass (Das and Ramana, [20]).

4) Finally, can related the relationship between amaxand field relative density (RD2) for the initial liquefaction by following equation.

$\frac{a_{\max }}{g}=\frac{\sigma_{d}}{2 \sigma_{3}} \times \frac{R D_{2}}{R D_{1}} \times \sigma_{v}^{\prime} \times \frac{C_{r}}{0.65 \times r_{d} \times \sigma_{v}}$

It is now possible to prepare Table 6 to determine the variation of $a_{\max } / g$ with $R_{D(2)}$. It is important to mentionthat $R_{D(2)}$ is the relative density in the field. Figure (11) shows a plot of $a_{\max } / g$ versus the relative density as determined from Table (6). For this given soil (i.e., given $\mathrm{D}_{50}, \mathrm{~d}_{\mathrm{w}}$, and number of significant stress cycles $\mathrm{N}$ ), if the relative density in the field and amax/g are such that they plot as point $\mathrm{A}$ in Figure (11) (i.e., above the curve showing the relationship of Eq. (3)), then liquefaction would occur. On the other hand, if the relative density and $\mathrm{a}_{\max } / \mathrm{g}$ plot as point $\mathrm{B}$ [i.e., below the curve showing the relationship of Eq. (3)], then liquefaction would not occur. 


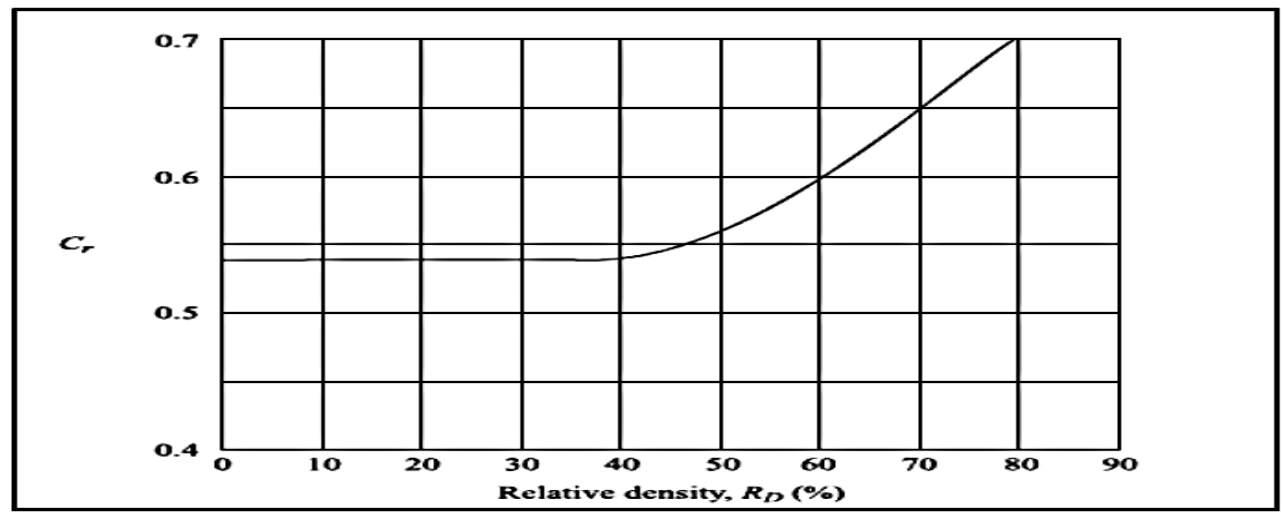

Fig. 9: Variation of $C_{r}$ with Relative Density (Das and Ramana, [20]).

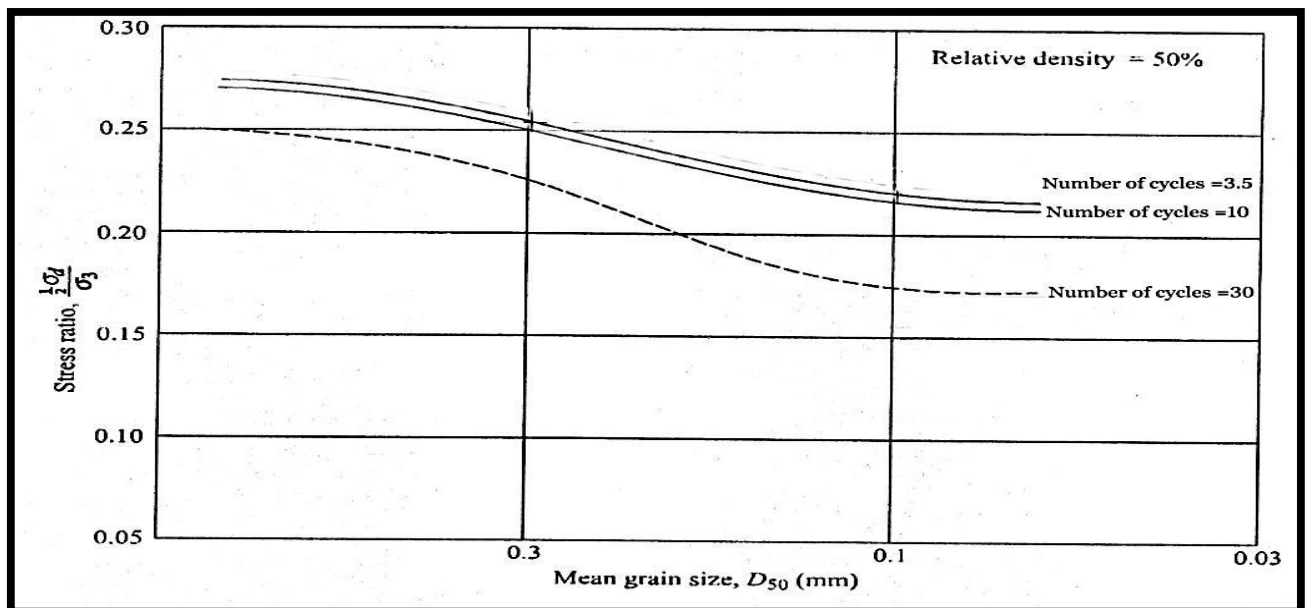

Fig. 10: Stress Ratio Causing Liquefaction of Sands in 3.5, 10 and 30 Cycles (Modified from Seed and Idriss, [5]).

Table 5: Some Geotechnical and Dynamic Properties for Site K3

\begin{tabular}{|c|c|c|c|c|c|c|}
\hline $\begin{array}{l}\sigma_{\mathrm{V}} \\
\mathrm{kN} / \mathrm{m}^{2}\end{array}$ & $\begin{array}{l}\tau_{\mathrm{av}} \\
\text { from equation(1) }\end{array}$ & $\begin{array}{l}\mathrm{D}_{50} \\
\mathrm{~mm}\end{array}$ & $\begin{array}{r}\text { Stress ratio } \\
\frac{\sigma_{\mathrm{d}}}{2 \sigma_{3}}\end{array}$ & $\sigma^{\prime} \mathrm{v} \mathrm{kN} / \mathrm{m}^{2}$ & $\begin{array}{l}\tau_{\mathrm{h}} \\
\text { from equation (2) }\end{array}$ & Equation (3) \\
\hline 73.3 & $45.26 \mathrm{a}_{\max } / \mathrm{g}$ & 0.2 & 0.24 & 60.56 & 0.2906.Cr. $\mathrm{RD}_{2}$ & $\mathrm{~A}_{\max / \mathrm{g}}=0.006420 . \mathrm{C}_{\mathrm{r}} \cdot \mathrm{R}_{\mathrm{D}(2)}$ \\
\hline
\end{tabular}

Table 6: Determination of the Variation of $A_{\max } / G$ with $R_{D(2)}$ for the Site $K 3$

\begin{tabular}{lll}
\hline \multicolumn{2}{c}{ Site-K3. S.P.T=9 blows/30 cm, depth $4 \mathrm{~m}$, W.T.L. $=2.7 \mathrm{~m}$} & \\
\hline R.D $(\%)$ & $\mathrm{Cr}$ & $\mathrm{a}_{\max } / \mathrm{g}$ \\
10 & 0.54 & 0.0346 \\
20 & 0.54 & 0.0693 \\
30 & 0.54 & 0.1040 \\
40 & 0.54 & 0.1386 \\
50 & 0.56 & 0.1736 \\
60 & 0.61 & 0.2349 \\
70 & 0.66 & 0.2966 \\
80 & 0.71 & 0.3646 \\
\hline
\end{tabular}

*Cr value is obtained from Figure 10.

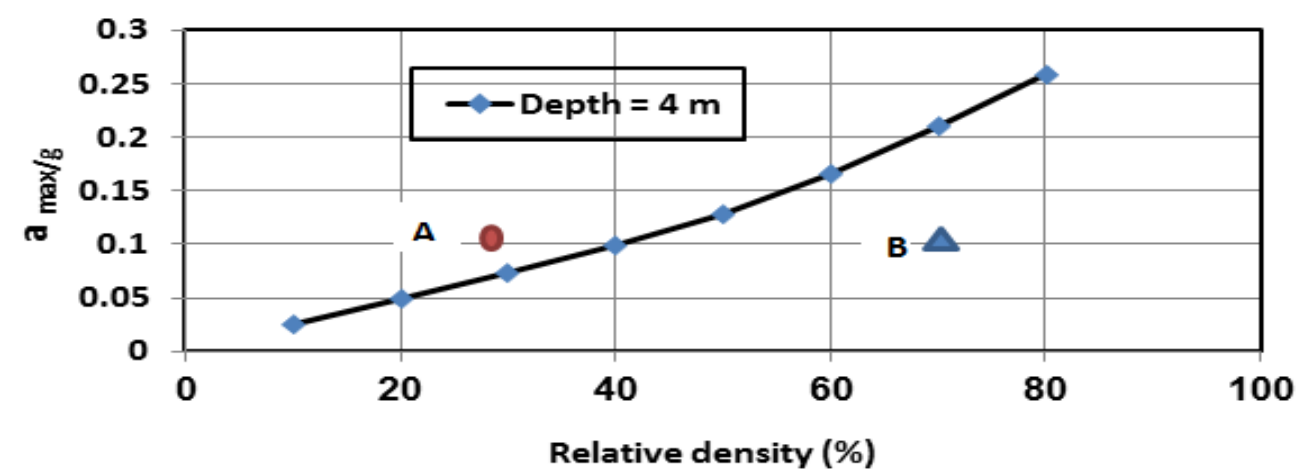

Fig. 11: Plot of $A_{\max } / G$ versus Relative Density for Prediction of Liquefaction Potential in Site K3 in Kerbala City, $N=3.5, D_{50}=0.2 \mathrm{Mm}$. 
From Figure 11, engineers and others can determine the liquefaction potential in any layer to any particular site such as (K3) with knowing the field relative density $\left(R_{D 2}\right)$ and the value of the maximum ground surface acceleration(a max $/ g$ ) for example $0.1 \mathrm{~g}$ as given in Table (7).

Case No. 2: New Kerbala Laboratory Building
From Figures 6 and 12 and Tables 8 and 9,liquefaction potential in siteNKL canbe determined.

Table 7: Determination of Liquefaction Potential from Figure 11 to Points Aand B in Site K3

\begin{tabular}{llllll}
\hline Points & Depth $(\mathrm{m})$ & S.P.T blows $/ 30 \mathrm{~cm}$ & R.D $(\%)$ & $\mathrm{a}_{\max } / \mathrm{g}$ & Liquefaction Potential \\
\hline A & 4 & 9 & 30 & 0.15 & Liquefaction occurs \\
B & 5 & 33 & 70 & 0.15 & No liquefaction \\
\hline
\end{tabular}

Table 8: Some Geotechnical Properties for Site NKL

\begin{tabular}{|c|c|c|c|c|c|c|}
\hline $\begin{array}{l}\sigma_{\mathrm{V}} \\
\mathrm{kN} / \mathrm{m}^{2}\end{array}$ & $\begin{array}{l}\tau_{\mathrm{av}} \\
\text { from equation (1) }\end{array}$ & $\begin{array}{l}\mathrm{D}_{50} \\
\mathrm{~mm}\end{array}$ & $\begin{array}{c}\text { Stress ratio } \\
\frac{\sigma_{\mathrm{d}}}{2 \sigma_{3}}\end{array}$ & $\sigma^{\prime} \mathrm{v} \mathrm{kN} / \mathrm{m}^{2}$ & $\begin{array}{l}\tau_{\mathrm{h}} \\
\text { from equation (2) }\end{array}$ & $\begin{array}{l}\text { Equation } \\
\text { (3) }\end{array}$ \\
\hline 62.94 & $37.63 \mathrm{a}_{\max } / \mathrm{g}$ & 0.15 & 0.23 & 41.87 & 0.1926.Cr. $\mathrm{RD}_{2}$ & $\mathrm{~A}_{\max / \mathrm{g}}=0.005118 . \mathrm{C}_{\mathrm{r}} \cdot \mathrm{R}_{\mathrm{D}(2)}$ \\
\hline
\end{tabular}

Table 9: Determination of the Variation of $A_{\max } / G$ with $R_{D(2)}$ in Site N.K.L

\begin{tabular}{lll}
\hline NKL-Site, S.P.T=15 blows/30cm, depth =3.5 m. W.T.L. $=1.35 \mathrm{~m}$ & $\mathrm{a}_{\max } / \mathrm{g}$ \\
\hline R.D $(\%)$ & $\mathrm{Cr}$ & 0.0276 \\
10 & 0.54 & 0.0552 \\
20 & 0.54 & 0.08291 \\
30 & 0.54 & 0.1105 \\
40 & 0.54 & 0.1433 \\
50 & 0.56 & 0.1873 \\
60 & 0.61 & 0.2364 \\
80 & 0.66 & 0.2907 \\
\hline
\end{tabular}

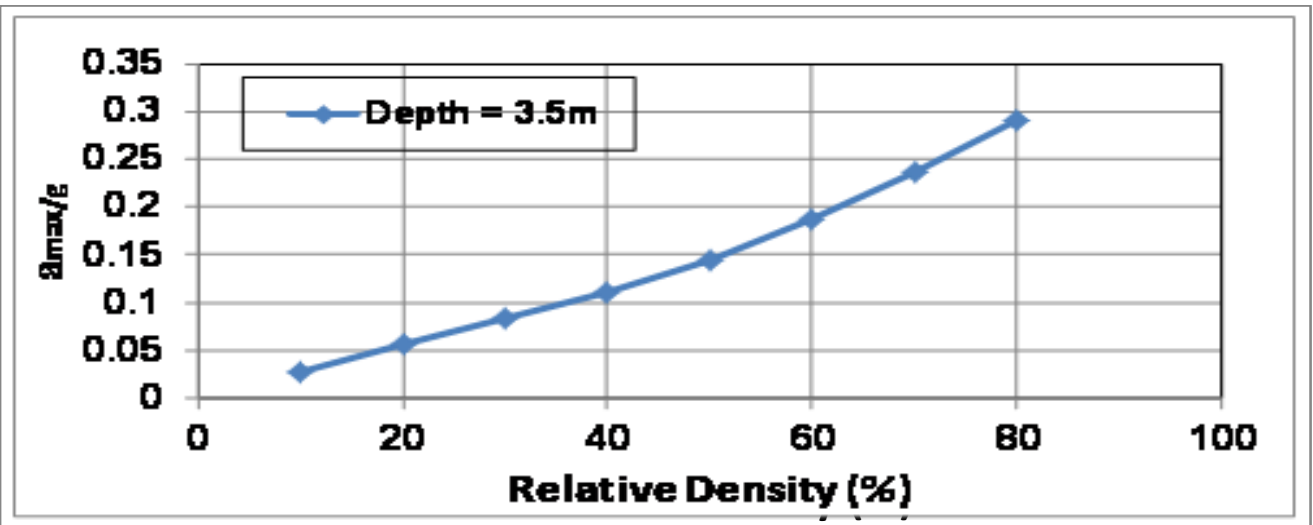

Fig. 12: Plot of $A_{\max } / G$ versus Relative Density for Prediction of Liquefaction Potential in Site N.K.L in Kerbala City, N = 3.5, $D_{50}=0.15$ Mm.

The design figures reveal that the studied sites in Kerbala city will be subjected to occurrence of liquefaction under an earthquake of maximum ground acceleration of $0.1 \mathrm{~g}$ when the soil is loose with a relative density between (25-40)\%.

Previous analyses showed that silty sands were found to possess more liquefaction resistance than uniform fine sands. Soils with rounded shapes were more susceptible to liquefaction, than angular grained soils. Required time to trigger liquefaction increased with fines content and depth of the soil sedimentation. Since the particle shapes of Kerbala sites are moistly rounded, these soils are probably susceptible to liquefaction and loss of shear strength due to low interlocking between particles. Soils with rounded particles are more susceptible to densify easily than soils with angular grains. Therefore, soils with rounded shapes are usually more susceptible to liquefaction than the angular-grained soils.

Gradation is a significant factor influencing liquefaction susceptibility. Poorly graded soils are more susceptible to liquefaction than well graded soils. Small particles are placed between large particles in well graded soils. Thus, lower volume change occurs under undrained conditions in well graded soils. Field evidences taken from some post-earthquake field investigations indicates that liquefaction failures occur mostly in uniformly poorly graded soils (Kramer, [21]).
According to the 1st Chinese criteria ( $\mathrm{Lu}$ et al., [22]), fine cohesive soils are potentially liquefiable type and character if :they include less than $15 \%$ clay fines with weight of grains having sizes smaller than the diameter $0.005 \mathrm{~mm} \leq 0.15$. This is exactly the case in Kerbalasites where most of soils in the layers are coarse grained.

Fattah et al. [23]showed that liquefaction and deformation develop fast with the increase of loading amplitude and frequency. Liquefaction zones increase with the increase of load frequency and amplitude. Tracing the propagation of liquefaction zones, one can notice that, liquefaction occurs first near the loading end and then develops faraway. The soil overburden pressure affects the soil liquefaction resistance at large depths. The liquefaction resistance and time for initial liquefaction increase with increasing depths.

\section{Conclusions}

1) The design figures reveal that sites in the study area will be subjected to occurrence of liquefaction under an earthquake of maximum ground acceleration of $0.15 \mathrm{~g}$ when the soil is loose with a relative density between $(25-40) \%$ in Kerbala city.

2) These curves show different locations of the study area prone to liquefaction hazard, liquefaction hazard curves 
could be used by engineers, planners and governmental organizations for future planning.

An increase in Ip decreased the soil potential to liquefy, and soil with $I_{P}>15$ seemed to be non-liquefiable, a finding that is in agreement with the results of other researchers. For the sites of the study area, the plasticity index, IP range between (NP-15\%) which indicates that the soils are liquefiable.

\section{References}

[1] Piya, B., K, (2004),"Generation of a Geological Database for the Liquefaction Hazard Assessment in Kathmandu Valley", M.Sc. thesis, International Institute for Geo-information Science and Earth Observation, Earth Resources and Environ mental Geoscience with the Specialisation in Natural Hazard Studies, Kingdom of Nepal.

[2] Karim, H. H., Fattah, M. Y., and Hasan, A. M., (2010) "Evaluation of Some Geotechnical Properties and Liquefaction Potential from Seismic Parameters" Iraqi Journal of Civil Engineering Vol. 6, No. 3, pp. 30-45

[3] Kahraman, I., (2013), "Seismic Liquefaction, 1-g Model Testing System and Shake Table Tests," M.Sc.thesis, School of Engineering and Sciences of İzmir Institute of Technology, Civil Engineering.

[4] Giannakogiorgos, A. Papathanassiou, G. and Vautherin, E. (2015), "Quantitative Assessment of Liquefaction Potential in Selected Areas in Christchurch, New Zealand," 6th International Conference on Earthquake Geotechnical Engineering, Christchurch, New Zealand.

[5] Seed, H. B. and Idriss, I. M. (1971). "Simplified Procedure for Evaluating Soil Liquefaction Potential", Journal of Soil Mechanics and Foundations Division, ASCE, (97) SM 9, pp. 1249-1273.

[6] Alsinawi, S. A. and Ghalib, A. A. (1975) "Seismic Zoning of Iraq", Proceedings of the 2nd Scientific Conference of the Foundation of Scientific Research (FSR), Baghdad.

[7] Alsinawi, S. A. and Al Qasrani, Z. O., (2003), "Earthquake Hazards Consideration for Iraq", Proceedings, Fourth International Conference of Earthquake Engineering and Seismology, Tehran, Iran.

[8] ASTM D- 1452-2012, "Standard Practice for Soil Exploration and Sampling by Auger Borings", American Society for Testing and Materials (ASTM)

[9] ASTM D- 5783- 2012, "Standard Guide for Use of Direct Rotary Drilling with Water-Based Drilling Fluid for Geoenvironmental Clay", Annual Book of ASTM Standards.

[10] Hassan, K. M., (2007),"Stratigraphy of Karbala-Najaf Area, Central Iraq", Iraqi Bulletin of Geology and Mining, Vol. 3, No. 2, pp. 5362.

[11] Bellen, R.C, Dunnington, H.V, Wetzel, R., and Morton, D, M.I., (1959),"Lexique Stratigraphic International", Vol.3, Asia Geology Cony, Comm., Stratigraphy. p.333.

[12] Al- Khateeb, A. A. G. Hassan, K. M., (2005). "Detailed Geologyical Survey for Mineral Exploration in Karbala-Najaf Area Baghdad Iraq", Report No. 2891, GEOSURV. 59 p.

[13] Barwary, A.M. and Slewa, N.A., (1995)." Geological Map of Karbala Quadrangle", scale 1:250000, sheet N1-38-14. GEOSURV, Baghdad.

[14] ASTM D 2216-2012 "Standard Method for Laboratory Determination of Water (Moisture) Content of Soil, Rock, and SoilAggregate Mixtures", Annual Book of ASTM Standards.

[15] ASTM D 4318-2012 "Standard Test Method for Liquid Limit, Plastic Limit, and Plasticity Index of Soils", Annual Book of ASTM Standards.

[16] ASTM D854- 2012 "Standard Test Method for Specific Gravity of Soils", Annual Book of ASTM Standards.

[17] ASTM D422-2012, "Standard test Methods for Particle-Size Analysis of Soils", Annual Book of ASTM Standards.

[18] ASTM D2487-2012 "Standard practice for Classification of Soils for Engineering Purposes", (Unified Soil Classification System), Annual Book of ASTM Standards.

[19] Seed, H. B., Idriss I. M., Makadisi, F., and Banerjee, N. (1975). "Representation of Irregular Stress Time Histories by Equivalent Uniform Stress Series in Liquefaction Analyses", EERC 75-29, Earthquake Engg. Reasearch Centre, University of California, Berkeley.

[20] Das, B. M., Ramana, V., G, (2011), "Principles of Soil Dynamics", Second Edition, Printed in the United States of America.

[21] Kramer, S.L., (1996), "Geotechnical Earthquake Engineering", Prentice - Hall International series in Civil Engineering and Engineering Mechanics, Prentice-Hall, New Jersey. 653 p.
[22] Lu, X., Tan, Q., Cheng, C.M., Yu, S. and Cui, P., (2004), "Liquefaction and Displacement of Saturated Sand under Vertical Vibration Loading", The Chinese Society of Theoretical and Applied Mechanics Chinese Journal of Mechanics Press, Beijing, China, Vol.20, No. 1, ISSN 567-7718.

[23] Fattah, M. Y., Al-Neami, M. A., Jajjawi, N. H., (2014), "Prediction of Liquefaction Potential and Pore Water Pressure beneath Machine Foundations", Central European Journal of Engineering, Vol. 4, (3), pp. 226-249. https://doi.org/10.2478/s13531-013-0165-y. 